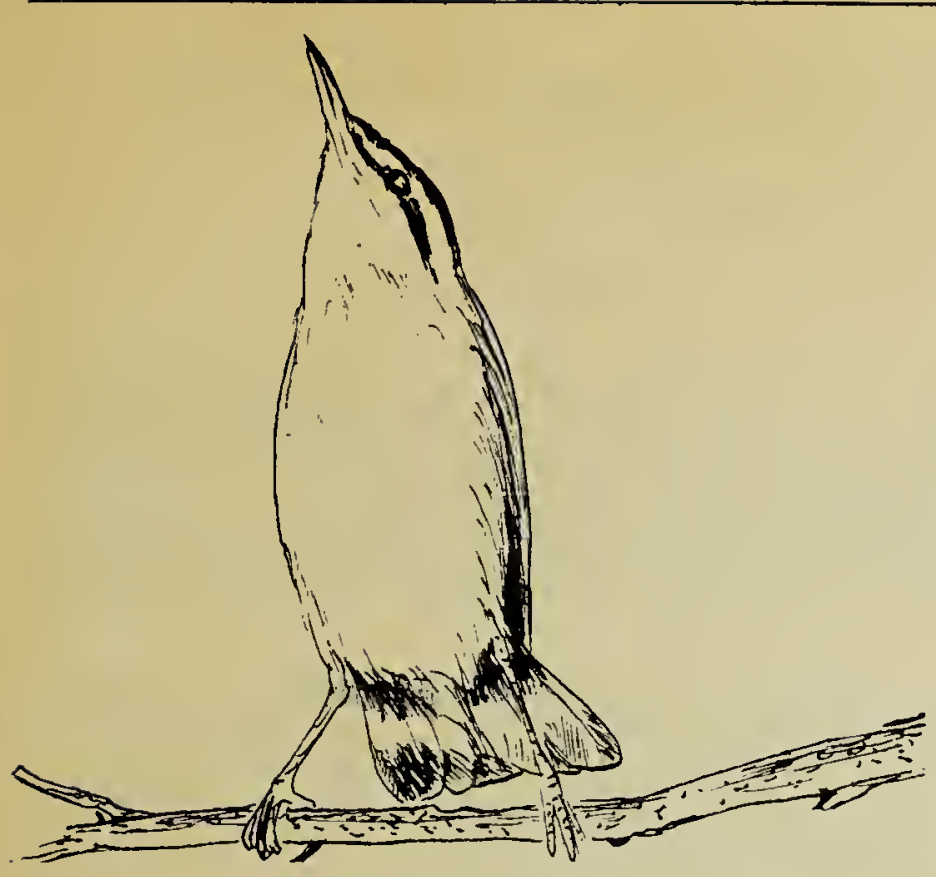

Drawing by Fred W. Lahrman. S.M.N.H.

what I had mistakenly taken to be the back of a warbler was actually the underparts of the nuthatch. In a moment it shook itself, as if suddenly recovering from some strain, as birds do, then began feeding in its usual manner. After a few seconds it flew away from the tree.

"Freezing" behaviour is not uncommon in birds and the protective value of remaining motionless in the presence of a predaitor is clear. I had at first overlooked the nuthatch right in front of my eyes, and found it only after some effort. I presume that nuthatches would not ordinarily react in this way to a human, but the surprise of unexpected appearance must have triggered this reaction. It seems peculiar for a bind to adopt the upside-down pasition for sudiden "freezing," but this position, of course, is characteristic of nuthatches.

Mrs. Louise de Kiriline Lawrence, Rutherglen, Ontario, has done considerable work with Red-breasted Nuthatches (see, for example, her "Irrepressible Nuthatch" in Audubon Book of True Nature Stories, 1958, Thomas Y. Crowell Co., New York), but she has not observed nuthatch behaviour as described above (pers. corres., 1960). However, she recalled somewhat similar behaviour in a Black-capped Chickadee:

"Many years ago I had an experience with a chickadee which, although not quite similar to yours, nevertheless immediately brought it to my mind. I was approaching the nest of a pair of chickadees to check just as the young were emerging. The parents became very upset. One of them flew toward me, but instead of attacking it alighted on a horizontal branch in front of me. Here it proceeded to swing itself down, as if falling, but holding fast with its feet, then swinging itself back into upright position again. This was done a number of times all along the branch, a perfectly fascinating performance of ups and downs.

"In this case it was obviously a distraction display. Apparently it was as natural for the chickadee to include the upside-down performance in its display as it was for your nuthatch, although in our minds neither display is commonly associated with this attitude."

\title{
KINGFISHER ESCAPE TACTICS
}

\section{by R. W. Nero, Sask. Museum of Natural History}

Recently, Thomas Heaslip submitted to me his records of bird observations made near Uranium City, Saskatchewan, from 1956 to 1960 (see Blue Jay, 17:57-58; Heasilip's present address: Loughries, Newtownards, Co. Down, N. Ireland). Among his notes there is included a description of behaviour in a Belted Kingfisher (Megaceryle alcyon) which closely resembles observations previously described for this species (Nero, R., 1949. Escape behaviour of a Kingfisher. Passenger Pigeon, 11:132). On July 14,1959 , Heaslip watched a Kingfisher hovering over a small lake near Lorado Mine. Suddenly, he writes, a Sparrow Hawk (Falco sparverius) appeared and closely pursued the Kingfisher. The latter dived down to the level of the water and then repeatedly plunged into it ("broke the surface"), each time sending up a shower of spray in front of the hawk, which finally gave up the chase. The earlier report describes a situation in which an aggressive male Redwinged Blackbird chased a Kingfisher until deterred in a similar way. In both of these cases the pursuer would appear to have been more of an annoyance than a danger. This suggests that these evasive tactics of the Kingfisher may be limited to encounters of this sort. 